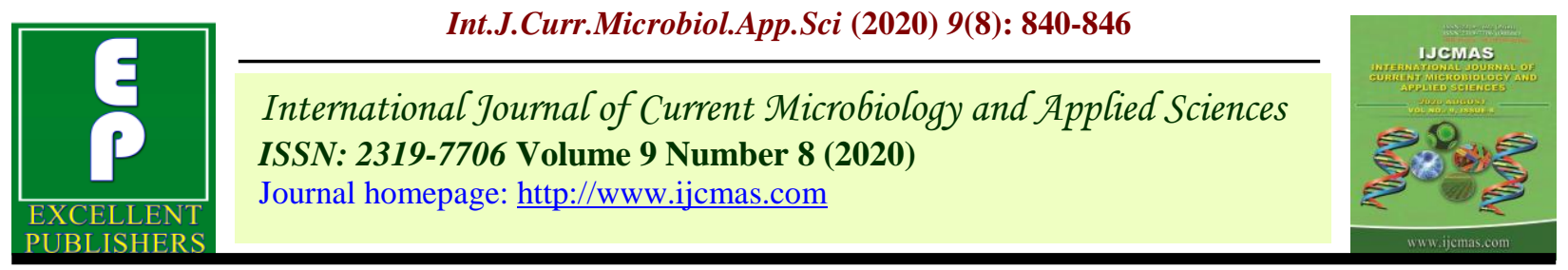

\title{
Impact of KVK Training on Promoting of TANUVAS Aseel as Backyard Chicken under ARYA Programme in Dharmapuri District, India
}

\author{
R. Thangadurai", M. A. Vennila, P. Ayyadurai and P. S. Shanmugam \\ ICAR-TNAU-KVK, Papparapatty, Dharmapuri-636 809, Tamil Nadu, India \\ *Corresponding author
}

\section{A B S T R A C T}

\section{Keywords}

TANUVAS Aseel, backyard poultry, Training, ARYA, Rural youth

\section{Article Info}

Accepted:

10 July 2020

Available Online:

10 August 2020
Majority of the people in the poorest places of Dharmapuri, TamilNadurely on poultry production as their major source of income and protein supply. However poultry production is hindered by low potential native chicken varieties and lack poor package of practices It is believed that training programme on promotion of Aseel released by Tamil Nadu Veterinary and Animal Sciences University (TANUVAS) during the year 2017 along with package practice for rural condition paying detail attention to the source of income generation and protein supply to the rural poor. Therefore the present study was undertaken in Dharmapuri district to know the impact of Krishi Vigyan Kendra (KVK) training on promoting of TANUVAS Aseel as backyard chicken under Attracting and Retaining youth in Agriculture (ARYA) programme among rural youth. Data collection regarding gain in knowledge and adoption level about improved poultry science technologies in backyard poultry farming were recorded before and after trainings. The results revealed that highest knowledge gain in importance of backyard poultry rearing (79.00\%) and least knowledge gain in economic character of backyard poultry (35.06\%). Regarding adoption level scavenging habit had highest adoption percentage $(56.67 \%)$ and least adoption eradication of ecto parasite and economic character of poultry $(24.45 \%)$ recorded. The overall performance of knowledge gain and adoption percentage had significant impact on uptake of new technologies.

\section{Introduction}

Backyard poultry (BYP) represent an appropriate system for supplying the fast growing human population with high quality protein and providing additional income to resource poor small farmers, especially youth. Requiring low level of inputs (i.e. housing, cages, feeds, breeds, vaccines, drugs, equipment and time/attention) (Mandal et al., 2006). BYP contributes significantly to food security, poverty alleviation and the ecologically sound management of natural resources. BYP produce being lower in quantum is almost consumed at the village level itself. Rural poultry sector though contributing nearly 30 per cent of the national egg production and this one is the most neglected one in the state. The fact is that village poultry eggs and meat fetch a much higher price than that of commercial hybrid poultry. However, 70 per cent of the poultry 
products and eggs are consumed in urban and semi urban areas and their consumption in rural areas is very low. This low consumption is attributed to limited availability and to some extent poor purchasing power of rural people.

The success of backyard poultry industry has increased greatly the number of individual employed. However, this growth has resulted also in a shift in the types of skills and competencies require to produce optimum industry profitability. Poultry farming has now become a remunerative business and preeminence over all other livestock enterprises in the developing countries. Backyard poultry farming play an important role in the economic development of the country (Nath et al., 2012). In general economic development refers to a process of upward changes of human resources which can be improved through increasing knowledge and attitude level of the rural take holders. Training is an integral and crucial input for the human resources development in all walks of life, be it agriculture, poultry rearing, animal husbandry, fisheries or any other field for bringing out desirable changes in human behaviour (Biswas et al., 2008). Poultry production in India emerges as poultry industry from backyard poultry production system. In recent days availability of poultry products in the rural areas is very low or unavailable due to their higher prices. Poultry farming is very old profession for providing cheap, readily harvest table protein rich eggs and meat with high quality of nutrients for home consumption.

In agriculture and allied sector contribution in National GDP is about 17.32 per cent with annual growth of 4.1 percent (Economic survery, 2016-2017). In agriculture and allied sector, Indian poultry sector is the major game changer with an overall growth of about $7-8 \%$ per annum $(0.7 \%$ in National GDP). At present condition, the Indian poultry sector has assumed much focus due to the growing demand for poultry products especially in urban areas because of their high food value. Many urban and rural populations have been supplementing nutrition with either for egg and meat. Eggs are very economical source of high quality protein, vitamins and minerals, while egg yolk contains additional cholesterol, fat soluble vitamins and essential fatty acids. The poultry birds are major source of lean meat with high nutritional value.

The growth of poultry industry has not been just a domestic phenomenon but has had a worldwide scope. Nowadays there is very rapid international transfer of products, information, and systems. The economics and agriculture sectors of individual countries are interconnected to those of rest of the world.

The native chicken varieties adopted in free range backyard condition for centuries contribute about 11 percent of total egg production in India (Kumaresan et al., 2008). Because to their low productivity (annual egg production @ 60-70 eggs/hen/year), their contribution to the total egg output was almost static for the last few decades. The role of backyard poultry farming in sustaining and enhancing poor people's livelihoods in developing countries is well recognized among the development community (Ahuja et al., 2008). There is also growing evidence to demonstrate the role of backyard poultry in enhancing the food and nutrition security of the poorest households, reducing the livelihood vulnerability and insecurity and promotion of gender equity (Ahuja and Sen, 2007). Backyard poultry is an important source of animal protein despite, the levels of monthly income from backyard poultry farming being very low.

In order to overcome this problem, it may be necessary to take up specific rural poultry 
production programmes with low input technology to meet the requirement of the rural sector, where poultry farming constitutes a source of subsidiary occupation, generating subsistence, income to boost the nutritional standards and health of rural masses. The rural family poultry (backyard poultry) units require very little hand feeding and provide handsome returns with minimum investment. Thus, rural poultry farming not only increase income levels, employment opportunities to small farmers including women but also bring about desired socio-economic change in rural areas which are vital for rural development and rural prosperity.

In Dharmapuri district most of the farmers are adopting poultry rearing under traditional pattern and lack of scientific knowledge on backyard poultry rearing with improved varieties (TANUVAS Aseel).For improving scientific knowledge on backyard poultry rearing in farmers of Dharmapuri district. KVK Dharmapuri has conducted training programme on scientific management of backyard poultry rearing under the Attracting and retaining of youth in agriculture (ARYA) programme. .

The study will aim to give quality training programme on scientific method of backyard poultry farming with TANUVAS Aseel chicken through KVK Dharmapuri substantially due to greater demand for improved poultry science technology by the young farmers. Backyard poultry population plays an important role in the national economy and socio-economic development of landless, small and marginal farmers by supplementing family income, nutrition and generating employment. Considering the technology offered by backyard poultry farming, Krishi Vigyan Kendra, Dharmapuri started scientific management of backyard poultry rearing. The training programme has been conducted with the following objectives includes to empower the rural youth to acquire knowledge in backyard poultry and also to facilitate in gaining knowledge and adoption level in poultry husbandry practices,

Skill development of rural youth will help in improving their confidence levels and encourage them to pursue farming as profession, generate additional employment opportunities to absorb under employed and unemployed rural youth in secondary agriculture and service related activities in rural areas. The trained youth group will function as role model for other youths and will demonstrate the potentiality of the agri based enterprises and also give training to other farmers.

\section{Materials and Methods}

KVK Dharmapuri has identified 90youth having less than 35 years of age for developing entrepreneurial aptitude on backyard back yard poultry. The entrepreneurial units were established at their location depending upon market potential of the enterprises. The purpose was to establish economic models for youth in the village so that youths get attracted in agriculture and overall rural situation is improved. The study was conducted in Dharmapuri district by Krishi Vigyan Kendra, Dharmapuri during 2018-2020 through ARYA programme funded by Zone X, ICAR-ATARI, Hyderabad. Interested farmers have divided into three groups, each group carries 30 farmers. Among 60 farmers received one day on campus training programme at $\mathrm{KVK}$ on selection, handling, feeding, breeding, disease management, hatchery operation and chick management and second day as esposure training at College of poultry production and Management (CPPM) Hosur. Off campus training programme along with exposure visit were also organized for last batch of 30 beneficiary farmers to visit their farm and confirm their adoption regarding scientific method of backyard poultry farming with 
TANUVAS Aseel chicken.

A set of questions related to the topic of training was prepared and it was given to the participants before starting of the training programme and same questions was again given at the end of the training programmes. Two sets of scores was obtained ie. Pre evaluation score and post evaluation score and Knowledge gain was calculated by using the formula

$$
\begin{aligned}
& \text { Post evaluation score - Pre evaluation score } \\
& \text { \% of Knowledge gain =-------------------------------------------- X } 100 \\
& \text { Total score }
\end{aligned}
$$

Percent of knowledge gain and adoption level were obtained for the individual training and presented in table

At last feedback collected from participants. Inpusts like TANUVAS Aseel day old chicks, deworming drug, drinker, waterer, feederer TANUVAS rural poultry cage, Azolla sheet, fodder seeds and training material were supplied. The selection of the beneficiary was done based on training programme, farmers data register, social media, newspaper, radio announcement, Kisan message and KVK Dharmapuri farmers whats app group from 2018-2020.

\section{Results and Discussion}

\section{Effectiveness of the training programme}

The gain in knowledge by the respondents about scientific methods of backyard poultry farming and Azolla feeding was measured in terms of percentage. The data regarding gain in knowledge about scientific method of backyard farming and feeding technologies were recorded under the head of pre evaluation and post evaluation.

The data presented in Table.1 with regards to the level of gain in knowledge revealed that, the beneficiary farmers of backyard poultry farming training programmes gained highest knowledge about importance of backyard poultry rearing $(79.00 \%)$. It was also found that a majority of the backyard poultry farmers gained highest knowledge about azolla feeding $(77.93 \%)$ followed by system of rearing (72.73),prevention of Ranikhet and Pox disease (72.66), scavenging habit $(70.50 \%)$,vaccination and deworming $(61.26 \%)$, identification of sex ratio $(56.26 \%)$, new variety $(51.86 \%)$,temperature and humidity in egg incubator (47.20\%), nutrition requirement $(44.93 \%)$, termite feeding $(44.86 \%)$,Eradication of eco parasite $(44.40 \%)$ and economic character $(35.06 \%)$

\section{Adoption of poultry rearing technologies}

Adoptations of poultry rearing technologies were presented in Table.2. which revealed that before training very few farmers were following the scientific method of backyard poultry farming and azolla feeding. Azolla feeding (51.11\%), vaccination and deworming (45.55),Prevention of Ranikhet and Pox disease $(38.88 \%)$,System of rearing $(37.77 \%)$, new variety (35.55\%),Identification Sex ratio (28.88\%), Eradication of eco parasite in BYP rearing $(26.66 \%)$,Scavenging habit(23.33\%),Feeding of green fodder (23.33\%), Termite feeding (18.88), Nutrition requirement (17.77),Economic character (15.55) and Temperature and Humidity in egg incubator (13.33).

Whereas after training programme the adoption level increased in scavenging habit(56.67 \%), New variety (Aseel) (55.56\%), System of rearing(45.56\%), Prevention of Ranikhet and Pox disease (44.45\%), Temperature and Humidity 5.in egg incubator (40.00\%), azolla feeding (38.89\%), Identification Sex ratio (35.56\%), Feeding of green fodder $(35.55 \%)$, Nutrition requirement for BYP (33.34\%), Termite 
feeding (32.23\%), Vaccination and parasite (24.45\%) and Economic character deworming (25.56\%), Eradication of eco $(24.45 \%)$

Table.1 Effectiveness of the training programme $(n=90)$

\begin{tabular}{|c|l|c|c|c|}
\hline $\begin{array}{c}\text { Sl. } \\
\text { No. }\end{array}$ & \multicolumn{1}{|c|}{ Technologies } & $\begin{array}{c}\text { Pre } \\
\text { Evaluation }\end{array}$ & $\begin{array}{c}\text { Post } \\
\text { Evaluation }\end{array}$ & $\begin{array}{c}\text { Knowledge gain } \\
(\%)\end{array}$ \\
\hline $\mathbf{1 .}$ & Importance of backyard poultry rearing(BYP) & 45 & 82 & 79.00 \\
\hline $\mathbf{2 .}$ & New variety (Tanuvas Aseel) & 32 & 54 & 51.86 \\
\hline $\mathbf{3 .}$ & System of rearing & 34 & 75 & 72.73 \\
\hline $\mathbf{4 .}$ & Identification Sex ratio for BYP & 26 & 58 & 56.26 \\
\hline $\mathbf{5 .}$ & Temperature and Humidity in egg incubator & 12 & 48 & 47.20 \\
\hline $\mathbf{6 .}$ & Nutrition requirement for BYP & 16 & 46 & 44.93 \\
\hline $\mathbf{7 .}$ & Prevention of Ranikhet and Pox disease & 35 & 75 & 72.66 \\
\hline $\mathbf{8 .}$ & Eradication of eco parasite & 24 & 46 & 44.40 \\
\hline $\mathbf{9 .}$ & Economic character & 14 & 36 & 35.06 \\
\hline $\mathbf{1 0 .}$ & Vaccination and deworming & 41 & 64 & 61.26 \\
\hline $\mathbf{1 1 .}$ & Azolla feeding & 46 & 81 & 77.93 \\
\hline $\mathbf{1 2 .}$ & Scavenging habit & 17 & 72 & 70.50 \\
\hline $\mathbf{1 3 .}$ & Termite feeding & 21 & 53 & 44.86 \\
\hline $\mathbf{1 4 .}$ & Feeding of green fodder(Agathi, subabul, & & 51.60 \\
\hline & Moringa) & & & \\
\hline
\end{tabular}

Table.2 Adoptionof poultry rearing technologies (n-90)

\begin{tabular}{|c|c|c|c|c|}
\hline \multirow[t]{2}{*}{ SI. No. } & \multirow[t]{2}{*}{ Technologies } & \multicolumn{2}{|c|}{ Adoption (\%) } & \multirow{2}{*}{$\begin{array}{c}\text { Increase of } \\
\text { Adoption level (\%) } \\
\text { after training }\end{array}$} \\
\hline & & Before training & After training & \\
\hline 1. & New variety (Aseel) & 35.55 & 91.11 & 55.56 \\
\hline 2. & System of BYP rearing & 37.77 & 83.33 & 45.56 \\
\hline 3. & Identification Sex ratio for BYP & 28.88 & 64.44 & 35.56 \\
\hline 4. & $\begin{array}{l}\text { Temperature and Humidity 5.in egg } \\
\text { incubator }\end{array}$ & 13.33 & 53.33 & 40.00 \\
\hline 5. & Nutrition requirement for BYP & 17.77 & 51.11 & 33.34 \\
\hline 6. & Prevention of Ranikhet and pox disease & 38.88 & 83.33 & 44.45 \\
\hline 7. & Eradication of eco parasite in & 26.66 & 51.11 & 24.45 \\
\hline 8. & Economic character of BYP & 15.55 & 40.00 & 24.45 \\
\hline 9. & Vaccination and deworming & 45.55 & 71.11 & 25.56 \\
\hline 10. & azolla feeding & 51.11 & 90.00 & 38.89 \\
\hline 11. & Scavenging habit & 23.33 & 80.00 & 56.67 \\
\hline 12. & Termite feeding & 18.88 & 51.11 & 32.23 \\
\hline 13. & $\begin{array}{l}\text { Feeding of green fodder (Agathi, subabul, } \\
\text { Moringa) }\end{array}$ & 23.33 & 58.88 & 35.55 \\
\hline
\end{tabular}


In study concluded that the ARYA training programme on scientific management of backyard poultry rearing has good impact on the rural youth on adoption of various technologies in scientific backyard poultry rearing. Among all the parameter scavenging habit had highest adoption percentage $(56.67 \%)$ and least adoption eradication of ecto parasite and economic character of poultry $(24.45 \%)$ were noticed. It was revealed that new technologies in poultry rearing practices are gaining much knowledge for higher income generation. Azolla and termite can be considered as part of feed replacing $30 \%$ of balanced feed. The overall adoption percentage by the rural youth indicated that training has a significant impact in updating new technologies for better economic return.

The training imparted to rural youth has increased the awareness about new technologies among the participants and improved their knowledge. Dharmapuri farmers are mostly financially poor to establish huge amount for new enterprises so they mainly depends poultry farming for their livelihoods as suggested by Pralhad, et al., 2020. Hence it is very much necessary to raise awareness about rearing of TANUVAS Aseel chicken along with package of practice for poultry rearing in Dharmapuri district. Besides reduction of poverty it will help in nutritional improvement especially in helpless group. It is not only gives employment to the rural youth and play a important role in women empowerment

\section{Acknowledgements}

The authors thankful to Tamil Nadu Agricultural University (TNAU),Coimbatore and ICAR-ATARI-Zone X, Hyderabad for providing administrative support and funding to KrishiVigyan Kendra, Dharmapuri for the execution of this study.

\section{References}

Ahuja V and Sen A. Viability and future of small scale commercial poultry production in developing countries. Paper presented at International Conference on poultry in the $21^{\text {st }}$ century: Avian Influenza and Beyond, Bangkok, 2007; November 5-7

Ajuja V, Dhawan M, Punjabi M and Maarse L. Poultry based livelihoods of rural poor: case of Kuroiler in West Bengal. National Dairy Development Board of Indian and Food and Agriculture Organiszation of the Uniter Nations, 2008 p 57.

Biswas, S., A.Sarkar and A.Goswami.Impact of KVK training on advance dairy farming practices (AFDPS) in changing knowledge and attitude of PraniBandhu.J.Dairying Foods Home Sci2008. 27(1): P43-46.

Kumaresan A, Bujarbaruah KM, Pathak KA Analysis of village chicken production system and performance of improved dual purpose chicken under a subtropical hill agro-ecosystem in India.Trop Anim Health Prod 2008:40,395-402.

Mandal MK, Khandekar N, Khandekar P. Backyard poultry farming in Bareilly district of Uttar Pradesh, Indaia: An analysis. Livestock Research for rural Development, 2006:18(7).

Nath BG, Pathak PK, Mohanty AK. Scientific backyard poultry rearing technologies: an approach to awareness and adoption of technology for livelihood development of rural farmers in Sikkim, India. Russian Journal of Agricultural and Socio Economic Sciences. 2013;22(10).

Pralhad, GS, Yadahalli,N, Sreedhara JN, Anupama C, Shreevani GN and Patil MC. Impact of KVK training on promotion of backyard poultry farming in Kalyankarnataka.

Int.J.Curr.Microbiol.App.Sci(2020)9(6): 407-411. 


\section{How to cite this article:}

Thangadurai, R., M. A. Vennila, P. Ayyadurai and Shanmugam, P. S. 2020. Impact of KVK Training on Promoting of TANUVAS Aseel as Backyard Chicken under ARYA Programme in Dharmapuri District, India. Int.J.Curr.Microbiol.App.Sci. 9(08): 840-846.

doi: https://doi.org/10.20546/ijcmas.2020.908.090 